\title{
PENGELOLAAN SCHOOL EMPOWERING PROGRAM DALAM MENGEMBANGKAN KEAHLIAN KHUSUS SISWA SEKOLAH MENENGAH ATAS
}

\author{
Chuswatul Nur Salamah \\ Achmad Supriyanto \\ Imam Gunawan \\ Universitas Negeri Malang, Jalan Semarang 5 Malang 65145 \\ chuswatulns@gmail.com
}

\begin{abstract}
This study aims to find out about school empowering management functions of programs, supporting and inhibiting factors in their implementation and efforts to overcome existing obstacles. This study uses a qualitative approach with a type of case study. Data collection techniques used are observation, interview and documentation. To check the validity of the data using data triangulation. The results of this study include school empowerment programs planning conducted before the new school year, compiling work programs, designing funding budgets and preparing $\mathrm{MoU}$ with other institutions, the composition of the school empowering program consists of principals, program leaders and school teaching staff empowering programs, conducting activities in the form of school empowering training programs with materials, practice and competency testing, evaluating school empowering programs when the activities take place by supervising the implementation of school empowering training programs and final evaluation of activities in the form of competency tests students follow after participating two years of training and getting a certificate in their respective fields of expertise, school empowering program supporting factors namely parental support and the availability of facilities and infrastructure. Factors that inhibit school empowering programs and limited costs. Efforts to overcome obstacles in training in school empowering programs are related to the problem of time constraints, namely by dividing students into several waves to participate in training activities in the classroom. For financing problems in procurement of proposals and infrastructure using priority scale.
\end{abstract}

Keywords : management; school empowering programs; special skills

Abstrak: Penelitian ini bertujuan untuk mengetahui tentang fungsi pengelolaan school empowering program, faktor pendukung dan penghambat dalam pelaksanaannya serta upaya dalam mengatasi hambatan yang ada. Penelitian ini menggunakan pendekatan kualitatif dengan jenis studi kasus. Teknik pengumpulan data yang digunakan yaitu observasi, wawancara dan dokumentasi. Untuk pengecekan keabsahan data menggunakan trianggulasi data. Hasil dari penelitian ini meliputi perencanaan school empowering program dilakukan sebelum tahun ajaran baru, menyusun program kerja, merancang anggaran dana dan mempersiapkan $\mathrm{MoU}$ dengan lembaga lain, susunan pengorganisasian school empowering program terdiri dari kepala sekolah, ketua program dan staf pengajar school empowering program, pelaksanaan kegiatan dalam bentuk pelatihan yang dilakukan school empowering program diantaraya pemberian materi, praktik dan uji kompetensi, evaluasi school empowering program pada saat kegiatan berlangsung dilakukan dengan mengawasi pelaksanaan pelatihan school empowering program dan evaluasi akhir kegiatan berupa uji kompetensi yang diikuti siswa setelah mengikuti pelatihan selama dua tahun dan mendapatkan sertifikat di bidang keterampilan masing-masing, faktor pendukung school empowering program yaitu dukungan orangtua dan ketersediaan sarana dan prasarana. Faktor penghambat kegiatan school empowering program dan keterbatasan biaya. Upaya mengatasi hambatan dalam pelatihan di school empowering program yang berkaitan dengan masalah keterbatasan waktu yaitu dengan membagi siswa menjadi beberapa gelombang untuk mengikuti kegiatan pelatihan di dalam kelas. Untuk masalah pembiayaan dalam pengadaan saranan dan prasarana menggunakan skala prioritas. 
Siswa harus diberikan pendidikan dan pembinaan dengan baik agar memiliki kompetensi sesuai dengan bakat dan minat yang dimilikinya. Sekolah perlu memberikan pembelajaran berupa pelatihan keahlian atau keterampilan bagi siswa yang tujuannya agar dapat memenuhi tuntutan dunia kerja. Pelatihan soft skills memperbaiki potensi seseorang, membuat tenaga kerja lebih fleksible, memiliki sikap positif untuk mudah berubah, mampu menangani berbagai perubahan tuntutan kerja dan lebih kompetitif(Rani, 2010). Terkait dengan pendidikan pada jenjang pendidikan menengah, Peraturan Pemerintah Nomor 29 Tahun 1990 Tentang Pendidikan Menengah menjelaskan bahwa tujuan sekolah menengah yaitu: (a) meningkatkan pengetahuan siswa untuk melanjutkan pendidikan pada jenjang yang lebih tinggi dan untuk mengembangkan diri sejalan dengan perkembangan ilmu pengetahuan, teknologi dan kesenian; (b) meningkatkan kemampuan siswa sebagai anggota masyarakat dalam mengadakan hubungan timbalbalik dengan lingkungan sosial, budaya dan alam sekitarnya.

Di SMA Islam Kepanjen selain menyiapkan siswa untuk melanjutkan pendidikan ke perguruan tinggi, juga memberi bekal kepada siswa dengan beberapa keterampilan yang dituangkan dalam sebuah program. Pemilihan program di sekolah haruslah sesuai dengan visi dan misi yang dimiliki sekolah. Dalam meningkatkan kualitas pendidikan di SMA Islam Kepanjen, maka disusunlah program khusus yang berbasis life skill. Penyelenggaraan program keahlian khusus di SMA Islam Kepanjen sebagai bentuk usaha untuk memberikan bekal kepada lulusan yang tujuannya agar dapat mandiri dengan keterampilan khusus sesuai bakat dan minat yang dimilikinya setingkat sekolah kejuruan. Hal tersebut sebagai langkah yang strategis, mengingat persaingan yang ada di masyarakat setelah menyelesaikan pendidikan sangat ketat. Terutama pada lulusan SMA yang memilih atau tidak bisa melanjutkan ke perguruan tinggi tetapi memilih melanjutkan ke dunia kerja. Anwar (2006) mengemukakan bahwa pengembangan pada jenjang SMA yang berorientasi keterampilan hidup dalam tidak bertujuan untuk memaksa sekolah untuk menerapkannya, akan tetapi sebagai suatu alternatif yang ditawarkan untuk berbagai kemungkinan atau pilihan yang dapat dipilih sesuai kondisi dan situasi yang nyata di dalam sekolah, yang ditinjau baik dari keberadaan siswanya maupun kehidupan dalam masyarakat.

School empowering program sebagai mata pelajaran tambahan dalam bidang keterampilan. Dengan memiliki tiga bidang keahlian yaitu desain grafis dan teknik komputer jaringan, otomotif serta tata boga. Setiap bidang keahlian tersebut, sekolah bekerjasama dengan lembaga atau instansi yang sesuai dengan bidang pelatihan yang bertujuan agar siswa yang telah lulus school empowering program mendapatkan sertifikat. Hasil penelitian Masruroh (2016) menunjukkan bahwa pelaksanaan vocational skill (keterampilan kejuruan) merupakan hasil dari yang diharapkan masyarakat yang selama ini diinginkan agar siswa tidak hanya meiliki kemampuan dalam akademik tetapi juga memiliki kecakapan keterampilan sebagai bekal untuk kehidupan di dalam masyarakat. Sedangkan hasil penelitian lain dari Suprihatin (2010) menunjukkan tujuan penyelenggaraan pendidikan kecakapan hidup vokasional di SMA adalah sebagai cara untuk peningkatan pada mutu alumni melalui pembekalan keterampilan bidang kejuruan bagi siswa khususnya bagi siswi dari keluarga tidak mampu yang potensi tidak dapat melanjutkan pendidikan ke jenjang yang tinggi.

\section{METODE}

Penelitian ini menggunakan pendekatan kualitatif dengan jenis penelitian studi kasus. Studi kasus adalah suatu metode untuk menyelidiki dengan langsung latar alamiah dan memusatkan perhatian dalam suatuu kejadian secara intensif dan rinci (Ulfatin, 2014). Penelitian ini bertujuan untuk mengadakan telaah yang mendalam terkait kasus yang ada , kesimpulan hanya akan berlaku atau terbatas dalam kasus tertentu. Alasan penggunaan pendekatan dan jenis penelitian kualitatif studi kasus pada penelitian ini disesuaikan dengan tujuan yang dirumuskan penelitian yaitu untuk mendeskripsikan pengelolaan school empowering program di SMA Islam Kepanjen.

Teknik pengumpulan data tersebut meliputi pengamatan (observasi), wawancara serta dokumentasi. Sumber data dalam penelitian ini yaitu Kepala SMA Islam Kepanjen, Ketua school empowering program, Wakil Kepala Sekolah bagian Kesiswaan, Pengajar school empowering program dan para siswa SMA Islam Kepanjen. Analisis data dilakukan dengan menggunakan langkah-langkah sesuai teori Miles, Huberman \& Saldana (2014) yaitu analisis data dilakukan dengan tiga langkah yaitu data 
condensation (kondensasi data), data display (menyajikan data), dan conclusion drawing and verification (menarik simpulan atau verifikasi). Kondensasi data merujuk proses diantaranya pemilihan (selecting), pengerucutan (focusing), penyederhanaan (simplifiying), peringkasan (abstracting), dan transformasi data (transforming).

Kriteria yang digunakan dalam pengecakan keabsahan data dalam peneliti ini yaitu kepercayaan (credibility). Teknik yang digunakan peneliti untuk menguji kepercayaan data yaitu dengan teknik triangulasi. Triangulasi merupakan teknik untuk pemeriksaan keabsahan data dengan memanfaatkan suatu hal lain di luar data yang diperoleh guna keperluan pengecekan juga digunakan pembanding terhadap suatu informasi (Moleong, 2002). Penelitian yang dilakukan di SMA Islam Kepanjen menggunakan triangulasi teknik, peneliti menggunakan teknik wawancara yang kemudian akan diperiksa kebenaran informasi dengan cara membandingkan beberapa informasi data dengan teknik observasi dan dokumentasi guna mendapatkan informasi data dari sumber yang sama. Dalam penelitian ini juga menggunakan triangulasi sumber. Triangulasi sumber dalam penelitian ini dilakukan dengan melakukan perbandingan antara informasi yang didapatkan dari satu sumber terhadap sumber lain melalui wawancara yang mendalam dengan informan.

\section{HASIL}

\section{Perencanaan School Empowering Program di SMA Islam Kepanjen}

Perencanaan school empowering program di SMA Islam Kepanjen dilakukan sebelum tahun ajaran baru, dalam kegiatan perencanaan ketua program menyusun program kerja serta merancang segala kebutuhan dalam school empowering program yang dituangkan dalam anggaran dana. Selain itu, dalam perencanaan school empowering program juga mempersiapkan perjanjian kerjasama dengan lembaga lain untuk mengembangkan keterampilan school empowering program.

\section{Pengorganisasian School Empowering Program di SMA Islam Kepanjen}

Pengorganisasian dalam pengelolaan school empowering program di SMA Islam Kepanjen terdapat beberapa personil yang terlibat di dalamnya. Setiap personil harus bertanggungjawab dalam melaksanakan tugasnya untuk kelancaran kegiatan yang dilaksanakan. Susunan pengorganisasian school empowering program di SMA Islam Kepanjen terdiri dari kepala sekolah, ketua program school empowering program dan staf pengajar school empowering program dalam tiga bidang keterampilan.

\section{Pelaksanaan School Empowering Program di SMA Islam Kepanjen}

Pelaksanaan kegiatan dalam bentuk pelatihan yang dilakukan school empowering program di SMA Islam Kepanjen diantaraya yaitu pemberian materi, praktik dan ujikompetensi.Pemberianmateri dilakukan untuk memberikan penjelasan bidang keterampilan yang akan dilaksanakan, selanjutnya praktikum yang menjadi fokus dalam pembelajaran ini. Bidang keterampilan yang ada di school empowering program meliputi otomotif, teknik komputer dan jaringan serta tata boga. Karena school empowering program ini merupakan mata pelajaran keterampilan yang menuntut siswa dapat menghasilkan sebuah karya, maka dilakukan upaya dalam mengembangkan keahliannya dengan mengikutsertakan siswa dalam festival lomba. Setelah dilaksanakan pembelajaran selama dua tahun maka dilaksanakannya uji kompetensi dengan pihak yang bekerjasama sebagai evaluasi school empowering program. Pelaksanaan pelatihan dalam school empowering program dapat dilihat pada Gambar 1 hasil dari dokumentasi pribadi penulis saat melakukan observasi di dalam kelas bidang keterampilan tata boga.

\section{Evaluasi School Empowering Program di SMA Islam Kepanjen}

Evaluasi school empowering program di SMA Islam Kepanjen pada saat kegiatan berlangsung dilakukan dengan mengawasi proses pembelajaran dalam pelatihan school empowering program. Untuk evaluasi akhir kegiatan berupa uji kompetensi yang diikuti siswa setelah mengikuti pelatihan selama dua tahun. Hasil uji kompetesi tersebut berupa sertifikat di bidang keterampilan masing-masing. Ketua program juga melakukan evaluasi terhadap pengajar school empowering program dengan melakukan pengawasan terhadap kehadiran pada saat mengajar. Yang terlibat dalam evaluasi kegiatan ini yaitu ketua 
program dan semua pengajar school empowering program, keterlibatan kepala sekolah dalam evaluasi program setiap selesainya kegiatan apabila ada sesuatu yang mendesak yang harus diselesaikan. Hasil uji kompetensi school empowering program berupa sertifikat dapat dilihat pada Gambar 2.

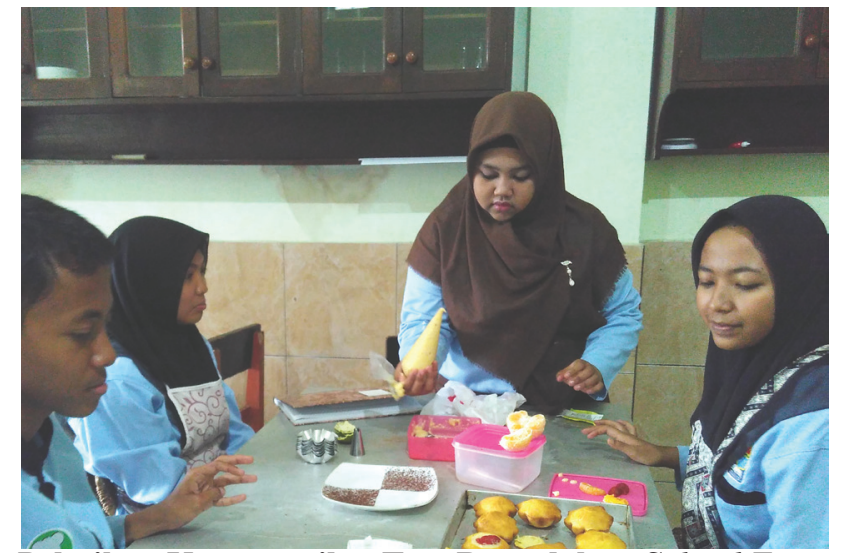

Gambar 1. Pelaksanaan Pelatihan Keterampilan Tata Boga dalam School Empowering Program di SMA Islam Kepanjen

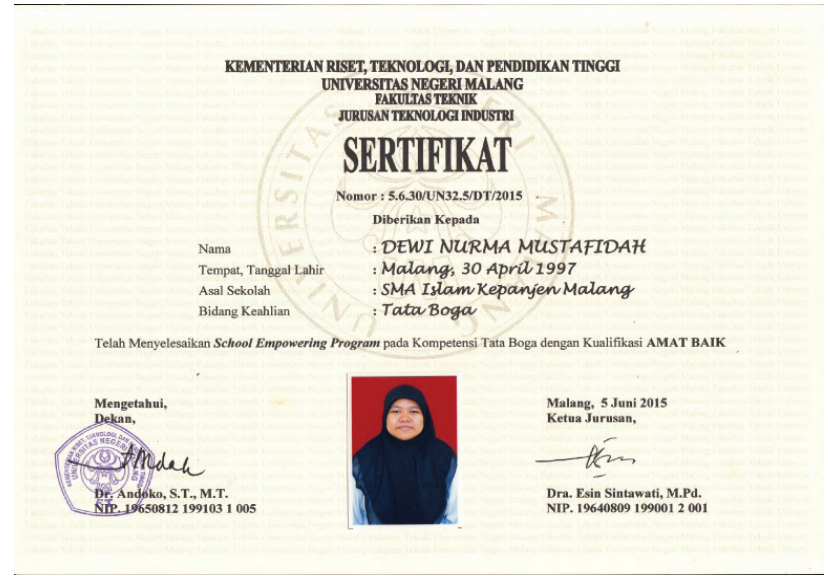

Gambar 2. Sertifikat School Empowering Program dalam Bidang Keterampilan Tata Boga Faktor Pendukung Dan Penghambat dalam School Empowering Program di SMA Islam
Kepanjen

Faktor pendukung school empowering program di SMA Islam Kepanjen yaitu dukungan orangtua dan ketersediaan sarana dan prasarana. Dukungan dari orangtua yaitu berupa dana dan motivasi yang diberikan kepada anaknya untuk aktif mengikuti kegiatan school empowering program. Untuk ketersediaan sarana prasarana telah memenuhi standar dan dapat membantu pelaksanaan pelatihan khususnya pembelajaran siswa di kelas. Faktor utama yang menghambat yaitu waktu. Keterbatasan waktu ini mengakibatkan kurang maksimalnya proses pembelajaran, karena pelaksanaan school empowering program ini hanya dua jam di setiap hari sabtu. Sehingga untuk bersaing dengan siswa SMK tidak bisa karena kalah dengan waktu belajar yang ditempuh. Masalah dana juga menjadi penghambat kegiatan school empowering program, karena dana berasal dari SPP siswa maka pengelolaannya berada di bendahara sekolah.Sehingga jika ingin membeli peralatan yang canggih, pengelola harus mengajukan kepada sekolah untuk membeli barang tersebut.

\section{Upaya Mengatasi Hambatan dalam School Empowering Program di SMA Islam Kepanjen}

Upaya SMA Islam Kepanjen dalam mengatasi hambatan dalam pelaksanaan pelatihan yang berkaitan dengan masalah keterbatasan waktu yaitu dengan membagi siswa dalam beberapa gelombang untuk masuk ke kelas dalam mengikuti kegiatan. Komunikasi antar pengelola dalam school empowering program sangat penting agar tidak ada masalah yang dapat mengganggu pembelajaran school empowering program. Untuk masalah pembiayaan, SMA Islam Kepanjen dalam pengadaan saranan dan prasarana 
menggunakan skala prioritas. Penggunaan skala prioritas dilakukan untuk memenuhi kebutuhan sarana prasaranan yang diakibatkan oleh terbatasnya dana.

\section{PEMBAHASAN}

\section{Perencanaan School Empowering Program}

Perencanaan school empowering program, dari hasil penelitian yang diperoleh yaitu perencanaan school empowering program di SMA Islam Kepanjen dilakukan sebelum tahun ajaran baru, dalam kegiatan perencanaan ketua program menyusun program kerja serta merancang segala kebutuhan dalam school empowering program yang dituangkan dalam anggaran dana. Selain itu, dalam perencanaan school empowering program juga mempersiapkan perjanjian kerjasama dengan lembaga lain untuk mengembangkan keterampilan school empowering program. Perencanaan dalam school empowering program juga dilakukan dengan mengadakan rapat sebelum tahun ajaran baru. Dalam rapat tersebut ketua program menyusun program kegiatan sebagai rumusan dari tindakan untuk satu tahun ke depan dan di dalamnya terdapat jadwal pelaksanaan school empowering program. Hal tersebut seperti pendapat Herujito (2006) bahwa isi dari perencanaan yaitu rumusan dari tindakan-tindakan yang dibutuhkan untuk mencapai sebuah hasil yang dikehendaki sesuai sasaran serta tujuan yang diterapkan. Menurut Tim Dosen UI (2012), suatu perencanaan memiliki kedudukan yang sangat penting karena rencana tersebut fungsinya untuk merinci dan menjelaskan tujuan yang akan dicapai, serta memberi dasar dan memastikan seluruh kegiatan yang harus dilaksanakan guna mencapai tujuan yang ditetapkan. Kegiatan perencanaan dalam school empowering program diantaranya menyusun program kegiatan. Penyusunan program kegiatan dilakukan sebelum tahun ajaran baru. Setelah program tersebut telah dibuat maka disampaikan pada rapat yang diadakan sebelum tahun ajaran baru. Yang terlibat dalam rapat tersebut yaitu kepala sekolah, ketua program serta guru school empowering program. Dalam program kerja tersebut terdapat jadwal kegiatan pelaksanaan school empowering program. Dibuatnya jadwal pelaksanaan school empowering program sesuai dengan salah satu tahap dalam perencanaan. Menurut Benty \& Gunawan (2017) pentingnya membuat jadwal agar seluruh kegiatan yang sudah diurutkan, pelaksanaanya menjadi jelas, mengetahui wakrtu pelaksanaannya dan yang terlibat untuk bertanggungjawab di dalamnya. Sedangkan menurut Sahertian (1987) menjelaskan bahwa mengatur jadwal merupakan salah satu unsur pengaturan program pengajaran. Jadwal menunjukkan adanya tugas yang yang harus dilaksanakan guru dalam mengajar. Tugas itu menyangkut hubungan kerja antara berbagai pihak, khususnya murid-murid. Hal tersebut juga didukung oleh pendapat Ubaidah (2014) bahwa membuat suatu jadwal yaitu salah satu aktivitas yang sifatnya administratif di sekolah. Jadwal bertujuan untuk mengatur program dalam belajar mengajar yang berisi pemberian materi maupun praktik. Program lapangan dapat terlaksana dengan tertib sesuai ketentuan yang telah ditetapkan dengan menggunakan semua sumber daya yang ada dengan segala keterbatasannya. Selain itu, dalam perencanaan school empowering program pengelola dalam hal ini ketua program mengatur anggaran dana yang akan digunakan.

Pengaturan anggaran dana school empowering program dilakukan dengan mengajukan anggaran yang dibutuhkan kepada bendahara sekolah karena sumber dana program tersebut berasal dari SPP siswa. Hal tersebut didukung pendapat Gunawan \& Benty (2017) bahwa pengelolaan pendidikan sekolah dalam segala aktivitasnya memerlukan fasilitas, layanan, pelaksanaan program di sekolah dan penggajian memerlukan anggaran dana. Hal tersebut juga didukung oleh pendapat Ubaidah (2014) bahwa disusunnya alokasi dana yang ada harus didasarkan atas realita serta skala prioritas, karena jika dana tersebut sudah diterima, tidak akan mengalami kesulitan untuk memanfaatkannya karena sebelumnya telah melakukan perencanaan.

Perencanaan selanjutnya dalam school empowering program yaitu mempersiapkan MoU dengan lembaga yang bekerjasama. Dilakukannya kerjasama ini untuk membantu mengembangkan keahlian siswa dengan pihak yang lebih ahli di bidangnya. Ditinjau dari kepentingan hubungan sekolah yang diantaranya untuk mempertahankan kehidupan sekolah adalah untuk meningkatkan kualitas pendidikan dalam sekolah yang bersangkutan, mempermudah mendapatkan dukungan serta bantuan dari masyarakat untuk proses belajar bagi siswa dan mengajar bagi pendidik yang mengenai hal yang dibutuhkan 
dalam melaksanakan dan mengembangkan program di sekolah (Syari, dkk: 2018). Pentingnya MoU dalam kerjasama juga didukung oleh pendapat Yalianto \& Sutrisno (2015) bahwa optimalisasi dalam melakukan pengembangan sekolah dapat dilakukan dengan bekerjasama dengan lembaga terkait yang terkait dengan kompetensi dalam bidang keahlian yang tertuang dalam naskah perjanjian kerjasama atau biasa disebut dengan MoU. Jadi tujuan dari kerjasama dengan lembaga atau instansi di luar sekolah adalah untuk mempermudah sekolah dalam mengembangkan program yang diselenggarakan di sekolah. Agar memiliki hubungan kerjasama yang terjalin dengan baik maka dibuatlah perjanjian secara formal dalam bentuk MoU. Hubungan kerjasama dikembangkan dengan prinsip saling membantu antara kedua pihak, khususnya dalam mengembangkan sumber daya manusia serta peningkatan kemampuan di dalam suatu lembaga. Merencanakan suatu kegiatan yang akan dilaksanakan pada hakikatnya membuat sebuah rencana, keputusan terkait arah tujuan, tindakan mana yang akan dilakukan, dan penggunaan sumber daya yang ada. Rencana tersebut mengarah pada tujuan organisasi dan menentukan suatu prosedur terbaik sebagai cara untuk mencapainya.

\section{Pengorganisasian School Empowering Program}

Pengorganisasian dalam pengelolaan school empowering program, dari hasil penelitian yang dilakukan yaitu terdapat beberapa personil yang terlibat di dalamnya. Setiap personil harus bertanggungjawab dalam melaksanakan tugasnya untuk kelancaran kegiatan yang dilaksanakan. Susunan pengorganisasian school empowering program di SMA Islam Kepanjen terdiri dari kepala sekolah, ketua program dan staf pengajar school empowering program. Hal tersebut sesuai dengan yang diungkapkan Sunandar (2012) bahwa struktur organisasi adalah suatu sistem tugas bersifat formal serta laporan keterkaitan antara koordinasi, motivasi dan pengawasan terhadap pegawai sehingg dapat menjadi satu untuk bekerjasama guna mencapai tujuan suatu organisasi. Semakin jelas struktur organisasi beserta tugas wewenang individu yang terlibat dalam suatu struktur maka dipastikan organisasi tersebut akan lebih baik dalam mengerjakan suatu pekerjaan. Hal tersebut juga didukung oleh pendapat Fattah (2004) bahwa pengorganisasian dilakukan untuk membagi suatu pekerjaan ke dalam beberapa tugas yang diperkecil, memberikannya kepada individu-individu yang memiliki kemampuan serta mengoordinasikannya untuk mencapai tujuan organisasi secara efektif. Pengorganisasian dilaksanakan dalam rangka membagi tugas kepada individu-individu yang terlibat di dalamnya, yang selanjutnya tugas tersebut sebagai penggerak untuk mendorong seluruh anggota untuk melaksanakannya dengan motivasi tinggi serta penuh semangat (Kurniawati \& Roesminingsih, 2014). Dengan itu perlu adanya pembagian tugas yang jelas antara personil dalam kegiatan yang diselenggarakan di sekolah untuk kelancaran kegiatan tersebut. Pengorganisasian dalam pendidikan sangat penting dilakukan untuk membantu setiap individu yang terlibat di dalamnya bekerjasama untuk mencapai tujuan organisasi. Seperti pengelolaan school empowering program terdapat beberapa personil yang terlibat di dalamnya. Setiap personil harus bertanggungjawab dalam melaksanakan tugasnya untuk kelancaran kegiatan yang dilaksanakan untuk mencapai suatu tujuan. Semua personil yang terlibat dalam hal ini bekerjasama untuk kelancaran kegiatan school empowering program. Tugas kepala sekolah dalam pelaksanaannya yaitu membina dan mengontrol seluruh kegiatan yang dilaksanakan, ketua program mengelola kegiatan sesuai yang telah direncanakan dengan mengarahkan atau mempengaruhi bawahannya untuk melaksanakan tugas masing-masing dan pengajar mempunyai tugas dalam memberikan materi keterampilan, praktikum dan uji kompetensi.

\section{Pelaksanaan School Empowering Program}

Pelaksanaan kegiatan pelatihan di school empowering program dari hasil penelitian yang diperoleh diantaraya yaitu pemberian materi, praktik dan uji kompetensi. Di dalam pelaksanaanya, sekolah juga melakukan beberapa upaya dalam mengembangkan keahlian khusus siswa. Upaya tersebut dalam bentuk mengikutkan siswa dalam beberapa perlombaan yang diadakan oleh pemerintah di tingkat kabupaten/ kota maupun tingkat nasional. Pemberian materi dilakukan untuk memberikan gambaran awal pembelajaran yang akan dilaksanakan ke depannya.

Selanjutnya pelaksanaan praktikum yang menjadi fokus pada pembelajaran ini, pembelajaran lebih difokuskan pada praktikum karena school empowering program ini merupakan mata pelajaran 
keterampilan yang menuntut siswa dapat menghasilkan sebuah karya. Setelah dilaksanakan pelatihan selama dua tahun maka dilaksanakannya uji kompetensi oleh pihak yang bekerjasama sebagai evaluasi school empowering program. Hal tersebut didukung oleh teori menurut Nasution (2006) fungsi pelaksanaan atau penggerakan yaitu untuk mempengaruhi seluruh anggota dan organisasi melaksanakan tugas yang diberikan dengan antusias tinggi dan kesadaran yang baik. Menurut Fattah (2006) pelaksanaan menggambarkan bagaimana manajer atau pengelola mengarahkan dan mempengaruhi para bawahan, agar orang lain melaksanakan tugas yang esensial dengan menciptakan suasana menyenangkan untuk bekerjasama. menurut Husein (2009) menyatakan pelaksanaan merupakan implementasi dari perencanaan yang telah ditetapkan dengan melakukan tahapan pekerjaan yang sesungguhnya secara fisik maupun non fisik sehingga produk akhir sesuai sasaran dan tujuan yang ditetapkan.

Di dalam pelaksanaan pelatihan di school empowering program, pihak sekolah juga melaksanakan upaya dalam mengembangkan keahlian khusus siswa. Upaya tersebut dalam bentuk mengikutsertakan siswa dalam berbagai perlombaan yang diadakan pemerintah. Upaya tersebut dilakukan untuk mengembangkan hasil karya siswa agar mempunyai manfaat, nilai dan dapat melihat keberhasilan pembelajaran di school empowering program melalui keikutsertaan siswa dalam lomba tersebut. Dilakukannya pembinaan serta pengembangan terhadap siswa tujuannya agar memperoleh berbagai macam pengalaman dalam belajar yang dapat digunakan sebagai bekal kehidupan di masa depan. Siswa dalam mendapatkan pengetahuan dan pengalaman belajar ini, harus melakukan berbagai macam kegiatan (Kurniawati \& Roesminingsih, 2014). Menurut Gruber dkk (2009) pengembangan keterampilan profesional dan kompetensi di semua tahap karir kejuruan dapat dipahami dengan tepat hanya ketika menganalisis interaksi pembelajaran formal daripada membandingkannya.Upaya-upaya dalam mengembangkann keahlian siswa dilakukan untuk meningkatkan keterampilan agar mempunyai pengetahuan, wawasan yang luas serta pengalaman sehingga siswa setelah lulus dapat bekerja sesuai bidang yang diminatinya.

\section{Evaluasi School Empowering Program}

Evaluasi school empowering program dari hasil penelitian yang diperoleh bahwa evaluasi program dilakukan pada saat kegiatan berlangsung oleh ketua program dengan mengawasi kehadiran pengajar di dalam kelas. Pada waktu tertentu ketua program juga mengunjungi langsung ke kelas untuk melihat proses pelatihan yaitu pembelajaran di dalam kelas. Jika ketua program berhalangan hadir, pengajar akan melaporkan kegiatan pada hari itu melalui grup WhatsApp. Hal tersebut dilakukan setiap kegiatan school empowering program agar tidak terjadi masalah yang dapat mengganggu pembelajaran. Keterlibatan kepala sekolah dalam evaluasi tersebut apabila ada sesuatu yang mendesak saja. Jika tidak ada sesuatu yang mendesak maka yang terlibat yaitu ketua program dan seluruh pengajar school empowering program. Pendapat ini sejalandengan Wibowo (2013) yang mengatakan bahwa, pengawasan ialah proses untuk mememantau, menilai, melaporkan tujuan yang dicapai untuk diperiksa guna menyempurnakan kegiatan selanjutnya. Adapun kegiatan dalam pengawasan yaitu mengamati kegiatan tersebut sesuai dengan apa yang direncanakan serta mengamati kegiatan tersebut apakah sudah sesuai dengan tujuan yang diharapkan. Sesuai dengan pendapat Herujito (2001), pengawasan merupakan sebagai aktivitas dalam menyesuaikan antara pelaksanaan berbagai rencana yang telah ditetapkan. Pengawasan digunakan untuk memastikan pekerjaan yang dilakukan telah sesuai dengan yang diharapkan oleh administrator, yang mana dalam hal ini pengawasan sebagai fungsi administratif (Sutisna, 1983). Evaluasi pada akhir kegiatan school empowering program yaitu berupa uji kompetensi. Siswa yang dapat mengikuti uji kompetensi tersebut yaitu siswa kelas XI yang telah menempuh school empowering program selama dua tahun. Jika lulus dalam uji kompetensi tersebut, maka pembelajaran dikatakan berhasil. Hal tersebut didukung oleh pendapat Agung \& Yufridwati (2013) bahwa evaluasi digunakan untuk mengetahui perkembangan pada hasil atau tujuan yang telah dicapai oleh sekolah, juga merupakan sebuah data atau informasi yang dibutuhkan untuk perencanaan dan penyusunan serta peningkatan kualitas pada kegiatan selanjutnya. Evaluasi ini juga untuk mengetahui sejauh mana manfaaat dari program bagi sekolah khususnya bagi siswa, mengalami pemborosan biaya atau tidak dan sebagainya. Hasil dari evaluasi ini memiliki manfaat bagi pengambil keputusan untuk menetapkan apakah dibutuhkannya keberlanjutan suatu program ekstrakurikuler (Ubaidah:2014). 
Jadi dapat disimpulkan bahwa evaluasi school empowering program wajib dilakukan untuk mengetahui perkembangan kegiatan untuk menjamin agar seluruh pekerjaan yang dilaksanakan berjalan sesuai tujuan yang telah direncanakan. Evaluasi dilaksanakan pada saat kegiatan berlangsung dan pada akhir kegiatan dilakukan dengan tujuan untuk mengatasi hambatan dalam pelaksanaanya.

\section{Faktor pendukung dan penghambat dalam School Empowering Program}

Faktor pendukung dalam pelatihan di school empowering program yang diperoleh dari hasil penelitian yaitu dukungan orangtua dan ketersediaan sarana dan prasarana. Dukungan dari orangtua yaitu berupa dana dan motivasi yang diberikan kepada anaknya untuk aktif mengikuti kegiatan school empowering program. Untuk ketersediaan sarana prasarana telah memenuhi standar dan dapat membantu pelaksanaan pelatihan siswa di kelas. Beberapa faktor yang telah peneliti peroleh mengutip dari pendapat Syah (2003) bahwa faktor eksternal yang mempengaruhi belajar siswa salah satunya faktor lingkungan nonsosial yang termasuk ke dalam faktor instrumental berupa hardware, seperti gedung sekolah, alatalat belajar dan fasilitas belajar. Selain itu, Arikunto (1990) berpendapat bahwa sarana atau fasilitas dibedakan atas dua jenis yaitu (a) fasilitas fisik, dan (b) fasilitas uang, (3) perhatian orangtua yang baik, orangtua memberikan persetujuan dan mengetahui kegiatan school empowering program yang diikuti oleh siswa. Menurut Mukhtar dan Iskandar (2013) fasilitas di sekolah adalah bagian penting yang mempengaruhi secara langsung serta dapat mendukung kegiatan dalam proses belajar mengajar di sekolah, dengan demikian fasilitas ini mutlak harus ada di sekolah. Dengan tersedianya fasilitas yang lengkap di sekolah, maka dapat mempermudah siswa dalam belajar karena peralatan yang dibutuhkan telah siap digunakan.

Dari hasil penelitian tentang faktor penghambat school empowering program, faktor utama yang menghambat dalam pelaksanaan pelatihan di school empowering program yaitu waktu. Menurut Hakim (2010) faktor yang mempengaruhi keberhasilan belajar berasal dari luar diri siswa yaitu waktu. Waktu yang dirasa kurang mengakibatkan kurang maksimalnya proses pembelajaran, karena pelaksanaan pelatihan ini hanya dua jam di setiap hari sabtu. Untuk bersaing dengan siswa SMK tidak bisa karena kalah dengan waktu belajar yang ditempuh. Masalah dana juga menjadi penghambat kegiatan school empowering program, karena dana berasal dari SPP siswa maka pengelolaannya berada di bendahara sekolah.Sehingga jika ingin membeli peralatan yang canggih, pengelola harus mengajukan kepada sekolah untuk membeli barang tersebut. Dengan faktor penghambat yang ada dalam pelaksanaannya, maka dapat meningkatkan kualitas serta kelancaran suatu kegiatan jika dilakukan penanganan dan pengelolaan yang baik dan benar (Septiani \& Wiyono, 2012). Faktor-faktor penghambat tersebut harus diminimalisir dengan baik, agar tidak mengganggu pelaksanaan kegiatan yang telah direncanakan maka pengelola harus bekerjasama dengan berbagai pihak untuk menemukan alternatif pemecahan masalah dalam menghadapinya.

\section{Upaya Mengatasi Hambatan dalam School Empowering Program}

Dari hasil penelitian yang diperoleh, cara untuk mengatasi hambatan yang berkaitan dengan masalah keterbatasan waktu yaitu yaitu membagi siswa dalam beberapa gelombang untuk mengikuti pelatihan di school empowering program. Komunikasi antar pengelola dalam school empowering program sangat penting agar tidak ada masalah yang dapat mengganggu pelaksanaan pelatihan khususnya pembelajaran school empowering program. Selain itu, dari pihak sekolah telah memberikan motivasi kepada siswa untuk aktif mengikuti kegiatan school empowering program. Untuk masalah pembiayaan kegiatan, sekolah menggunakan skala prioritas dalam penggunaan dana sebagai cara agar dana digunakan secara tepat. Menurut Septiani dan Wiyono (2012) faktor penghambat yang dapat menggangu jalannya kegiatan dapat ditangani secara baik dan benar. Dengan dilakukannya penanganan yang baik dan benar, kegiatan ekstrakurikuler dapat meningkat lebih baik serta dapat lebih berkembang. Strategi dalam pembelajaran yang bersifat produktif, serta didukung kreatifitas yang dimiliki oleh guru/instruktur maka dipercaya akan efektif serta efisien apabila dibandingkan dengan sistem yang sedang berjalan saat ini (Widarto, 2013). Untuk mendapatkan hasil yang baik dari suatu kegiatan, maka pengelola kegiatan harus memperhatikan bagaimana cara mengatasi masalah atau kendala yang dihadapi dengan baik sehingga tujuan dari kegiatan tersebut dapat tercapai sesuai yang telah direncanakan. Cara mengatasi hambatan 
tersebut dapat dilakukan dengan cara sekolah mengikutsertakan pengelola school empowering program dalam pelatihan dan pembinaan yang berkaitan dengan pengelolaan program kegiatan di sekolah yang di dalamnya meliputi penyusunan program kegiatan, pelaksanaan, evaluasi dan pengembangan program di sekolah dalam hal ini school empowering program. Untuk mengatasi pembiayaan dalam school empowering program, pengelola atau ketua program hendaknya selalu memberikan pengertian baik kepada kepala sekolah, pengajar serta komite sekolah untuk mencari dana tambahan guna pengembangan school empowering program.

\section{SIMPULAN}

Pengelolaan school empowering program meliputi perencanaan school empowering program dilakukan sebelum tahun ajaran baru, menyusun program kerja, merancang anggaran dana dan mempersiapkan perjanjian kerjasama dengan lembaga lain. Pengorganisasian dalam pengelolaan school empowering program terdapat beberapa personil yang terlibat di dalamnya. Susunan pengorganisasian school empowering program di SMA Islam Kepanjen terdiri dari kepala sekolah, ketua program dan staf pengajar school empowering program. Pelaksanaan kegiatan dalam bentuk pelatihan yang dilakukan school empowering program di SMA Islam Kepanjen diantaraya yaitu pemberian materi, praktik dan uji kompetensi. Evaluasi school empowering program pada saat kegiatan berlangsung dilakukan dengan mengawasi proses pembelajaran dalam pelatihan school empowering program dan evaluasi akhir kegiatab berupa uji kompetensi yang diikuti siswa setelah mengikuti pelatihan selama dua tahun dan mendapatkan sertifikat di bidang keterampilan masing-masing. Faktor pendukung school empowering program yaitu dukungan orangtua dan ketersediaan sarana dan prasarana. Faktor utama yang menghambat yaitu waktu. Disamping itu masalah dana juga menjadi penghambat kegiatan school empowering program, karena dana berasal dari SPP siswa maka pengelolaannya berada di bendahara sekolah. Upaya mengatasi hambatan dalam pelaksanaan pelatihan di school empowering program yang berkaitan dengan masalah keterbatasan waktu yaitu dengan membagi siswa menjadi beberapa gelombang untuk mengikuti kegiatan pelatihan di dalam kelas. Untuk masalah pembiayaan dalam pengadaan saranan dan prasarana menggunakan skala prioritas. Segala sesuatu dalam school empowering program dikelola dengan baik untuk menghasilkan output sekolah menengah atas yang dapat mendapatkan keterampilan tambahan yang tidak kalah saing dengan siswa sekolah menengah kejuruan.

\section{REFERENCE}

Agung, I \& Yufridawati. 2013. Pengembangan Pola Kerja Harmonis dan Sinergis antara Guru, Kepala Sekolah dan Pengawas. Jakarta: Raja Grafindo Persada.

Anwar. 2006. Pendidikan Kecakapan Hidup (Life Skills Education) Konsep dan Aplikasi. Bandung: Alfabeta. Arikunto, S. 1990. Organisasi dan Administrasi Pendidikan Teknologi dan Kejuruan. Jakarta: Rajawali Pers. Benty, D. D. N \& Gunawan, I. 2017. Manajemen Pendidikan: Suatu Pengantar Praktik. Bandung: Alfabeta. Fattah, N. 2006. Landasan Manajemen Pendidikan. Bandung: Remaja Rosdakarya.

Gruber, H, Harteis, C \& Rehrl, M. 2009. Skill Formation Between Formal and Sittuated Learning. Vocational and Professional Learning, 226. Dari https://www.cambridge.org/core/books/skill-formation/vocational-andprofessional-learning-skill-formation-between-formal-and-situated-learning/8565F7FEBEFA4E611555037 02AFF7301.

Hakim, T. 2000. Belajar Secara Efektif. Jakarta: Puspa Swara.

Herujito. 2001. Dasar-Dasar Manajemen. Jakarta: Graspindo.

Kurniawati, E \& Roesminingsih, E. 2014. Manajemen Kesiswaan Di SMA Negeri Mojoagung Jombang. Jurnal Inspirasi Manajemen Pendidikan 4(4) 207-213. Dari http://unesa.ac.id.

Masrurroh. Z. 2016. Manajemen Pendidikan Keterampilan (Vocational skill) di MAN Kembangsawit. Muslim Heritage: Jurnal Dialog Islam dengan Realitas 1(2), 417- 438. Dari http://jurnal.stainponorogo.ac.id/index. php/muslimheritage.

Miles, M.B, Huberman, A.M, \& Saldana,J. 2104. Qualitative Data Analysis, A Methods Sourcebook. USA: Sage Publications. Terjemahan Tjetjep Rohidin, UI Press. 
Moleong, L. J. 2002. Metode Penelitian Kualitatif. Bandung: PT Remaja Rosdakarya.

Mukhtar \& Iskandar. 2013. Orientasi Baru Supervisi Pendidikan. Jakarta: Gaung Persada.

Pardjono. 2003. Kecakapan Hidup (Life skill) dan Urgensinya Bagi Sekolah Menengah Kejuruan. LPM UNY: Jurnal Pendidikan Teknologi dan Kejuruan.

Pardjono. 2003. Pendidikan Kejuruan dengan Kurikulum Berbasis Kompetensi Berorientasi Kecakapan Hidup, Makalah Disampaikan dalam Lokakarya Pembelajaran dengan KBK Berorientasi Kecakapan Hidup. Tanggal di FT UNY, Yogyakarta, 29 dan 30 April.

Peraturan Pemerintah Nomor 29 Tahun 1990 tentang Pendidikan Menengah.

Rani, E.M.S. 2010. Need and importance of soft skills in student. Summer: Associate Professor in English, Sri Sarada College for Women, Salem. Dari https://docplayer.net/29565954-Need-and-importance-of-soft-skillsin-students.html.

Septiani, I \& Wiyono, B. B. 2012. Manajemen Kegiatan Ekstrakurikuler dalam Meningkatkan Kualitas Sekolah. Jurnal Manajemen Pendidikan 23(5), 424-433. Dari http://ap.fip.um.ac.idPDF manajemen kegiatan ekstrakurikuler dalam meningkatkan kualitas sekolah.

Sunandar, A. 2012. Keterhubungan Struktur dan Budaya Organisasi. Manajemen Pendidikan 23(6), 403-410. Dari http://ap.fip.um.ac.id/wp-content/uploads/2015/05/2-Asep-Sunandar.pdf.

Suprihatin, W.E. 2010. Manajemen Pendidikan Kecakapan Hidup Vocational Unggulan (Vocational Life Skills) Studi Multi Kasus di SMA Negeri 1 Tempeh Lumajang dan SMA Muhammadiyah 03 Batu Malang. Dari http://karyai-ilmiah.um.ac.id/index.php/disertasi/article/view/4930.

Sutisna, O.1983. Administrasi Pendidikan Dasar Teoritis untuk Praktek. Bandung: Alfabeta.

Syah, M. 2003. Psikologi Belajar. Jakarta: Raja Grafindo Persada.

Syari, I. A, Imron, A \& Arifin, A. 2018. Manajemen Hubungan Sekolah dengan Dunia Usaha dan Industri dalam Meningkatkan Prestasi Belajar Peserta Didik Sekolah Menengah Vokasional. JAMP: Jurnal Administrasi dan Manajemen Pendidikan 1(3), 313-319. Dari http://journal2.um.ac.id/index.php/jamp/ISSN 2615-8574.

Tim Dosen Administrasi Pendidikan UI. 2012. Manajemen Pendidikan Cetakan ke-5.Bandung: Alfabeta.

Ubaidah, S. 2014. Manajemen Ekstrakurikuler dalam Meningkatkan Mutu Sekolah. Al-Fikrah: Jurnal Kependidikan Islam 5(1), 155. Dari http://e-journal.iainjambi.ac.id/index.php/alfikrah/article.

Ulfatin, N. 2013. Metode Penelitian Kualitatif di Bidang Pendidikan: Teori dan Aplikasinya. Malang: Universitas Negeri Malang.

Wibowo, A. 2013. Manajemen Pendidikan Karakter di Sekolah. Yogyakarta: Pustaka Pelajar.

Widarto. 2013. Model Pendidikan Vokasi. Dari http://staffnew.uny.ac.id/upload/131808327/penelitian/ Model+Pendidikan+Vokasi.pdf.

Yalianto, Y \& Sutrisno, B. 2014. Pengelolaan Kerjasama Sekolah dengan Dunia Usaha/Dunia Industri (Studi Situs SMK Negeri 2 Kendal). Jurnal Pendidikan Ilmu Sosial 24(1), 19-37. Dari http:journals.ums.ac.id. 